\title{
Analisis Penggunaan Peramalan dalam Meminimalkan Biaya Simpan Produk Linzhi Plus pada CV. HN
}

\author{
Abdan Syakura ${ }^{1)}$, Oktiviandri Hendaryani ${ }^{2}$, Rafiq Ramadhan ${ }^{3)}$ \\ ${ }^{123)}$ Mahasiswa Program Studi Teknik Industri, Fakultas Teknik, Universitas Sebelas Maret \\ Jl. Ir. Sutami No 36A, Surakarta 57126
}

\begin{abstract}
$C V$. HN is a manufacturer of herbal supplements which products are mostly made from mushroom. Lingzhi Plus is one of their products. The product inventory data from October 2014 until September 2015 showed that the monthly average production was 111 units, the monthly average sales was 103 units, and the remaining product inventory at the end of the year was 108 units. The products that approaching the expiration date will be sold with a discount of $20 \%$. The high amount of remaining products leads to high production and storage cost. Therefore, companies should resolve the inventory control problem. This study proposes a method for controlling inventory and production by selecting the best demand forecasting method. The forecasting method MA4 shows the smallest error value which is known from MAD value of 30.66. By using the proposed method of forecasting, the company will earn saving of Rp 915,939.40 of inventory cost.
\end{abstract}

Keywords:inventory, forecasting, production

\section{Pendahuluan}

CV. HN merupakan produsen obat herbal yang sebagian besar bahan bakunya berasal dari jamur. Produk herbal yang diproduksi memiliki dua jenis, yaitu berbentuk sirup dan kapsul. Distribusi pemasaran dilakukan melalui oultet, apotik dan klinik herbal dan salespromotion (SP). Distribusi dilakukan pada wilayah pemasaran yang meliputi Solo Raya (Eks-Karesidenan Surakarta), Purwodadi, Semarang, Salatiga, Ungaran, Jogja, sebagian Jawa Barat dan Jakarta.

Perusahaan diharuskan untuk menarik kembali produk-produknya jika sisa masa kadaluarsa kurang dari lima bulan. Produk harus dikembalikan ke gudang pusat. Salah satu usaha meminimalkan produk return dilakukan perusahaan dengan memberikan potongan harga. Penjualan dengan potongan harga dilakukan untuk produk yang sisa masa kadaluarsanya antara lima bulan hingga satu tahun. Penjualan dengan potongan harga dilakukan secara langsung dengan salespromotion (SP) dan toko Kudu. Dengan demikian perusahaan harus mampu mengendalikan persediaan secara baik sehingga tidak terjadi kekurangan yang menyebabkan losssales serta kelebihan yang menyebabkan biaya produksi dan biaya penyimpanan yang tinggi. Permasalahannya, permintaan konsumen terhadap produk bersifat tidak pasti. Perusahaan sering mengalami kelebihan persediaan, padahal semakin mendekati masa kadaluarsa, perusahaan hanya bisa menjualnya setengah harga atau bahkan tidak dapat menjualnya. Sementara itu, biaya inventori masih dibebankan kepada perusahaan.

Untuk mengatasi permasalahan di atas maka perlu dilakukan metode pengendalian persediaan yang lebih baik. Metode tersebut harus dapat menentukan jumlah permintaan yang tepat dengan meminimalkan biaya-biaya yang muncul seperti biaya simpan, biaya pesan, biaya stockout, dan biaya produk kadaluarsa.

\section{Tinjauan Pustaka}

Secara umum, peramalan adalah tafsiran. Namun, ada beberapa definisi peramalan menurut para ahli. Menurut Makridakis, dkk (1988) peramalan/ forecasting merupakan prediksi nilai-nilai sebuah variabel berdasarkan kepada nilai yang diketahui dari variabel tersebut atau

*Correspondance : syashindan@gmail.com 
variabel yang berhubungan. Meramal juga dapat didasarkan pada keahlian judgment, yang pada gilirannya didasarkan pada data historis dan pengalaman. Sedangkan menurut Elwood (1996), peramalan atau forecasting diartikan sebagai penggunaan teknik-teknik statistik dalam bentuk gambaran masa depan berdasarkan pengolahan angka-angka historis.

Peramalan tidak bisa dilakukan tanpa kesalahan (error). Peneliti hanya mampu mengusahakan agar kesalahan (error) terjadi seminimal mungkin (Hanke dan Reitsch, 1998). Menurut Ryu (2002), metode peramalan dibutuhkan karena perusahaan dituntut untuk mengambil keputusan dalam ketidak-pastian. Sehingga peramalan yang dilakukan dengan analisis dan perhitungan akan dapat lebih diterima dibandingkan dengan peramalan yang bersifat hanya menebak-nebak tanpa analisis dan perhitungan. Peramalan yang dilakukan dengan akurat akan menghasilkan manfaat berupa kepuasan pelanggan, personelopride, kepercayaan diri perusahaan, kontrol operasi perusahaan, dan profit atau status keuangan breakeven(Messersmith dan Miller, 1991).

Secara umum metode peramalan dapat dibagi dalam 2 kategori utama, yaitu metode kuantitatif dan metode kualitatif (Heizer dan Render, 2001). Metode kuantitatif dapat dibagi ke dalam deret berkala atau runtun waktu (timeseries) dan metode kasual, sedangkan metode kualitatif dapat dibagi menjadi metode eksploratoris dan normatif.

1. Metode kualitatif

Peramalan dengan metode kualitatif dilakukan dengan pertimbangan, yaitu data masa lalu belum pernah ada atau susah diperoleh, trend data masa lalu diperkirakan. Teknik yang digunakan adalah pendekatan eksploratoris dan pendekatan normatif.

2. Metode kuantitatif

Peramalan dengan metode kuantitatif dapat dilakukan dengan beberapa persyaratan, yaitu data masa lalu bisa diperoleh dan dapat dikuantifikasi, data masa lalu diperkirakan memiliki trendyang sama dengan data masa yang akan datang. Metode yang digunakan antara lain metode constan, linear trend, exponential, movingaverage, dan eksponentialsmoothing.

Jenis pola data pada peramalan, yaitu :

a. Pola horizontal(H)terjadi bilamana data berfluktuasi disekitar nilai rata-rata yang konstan.

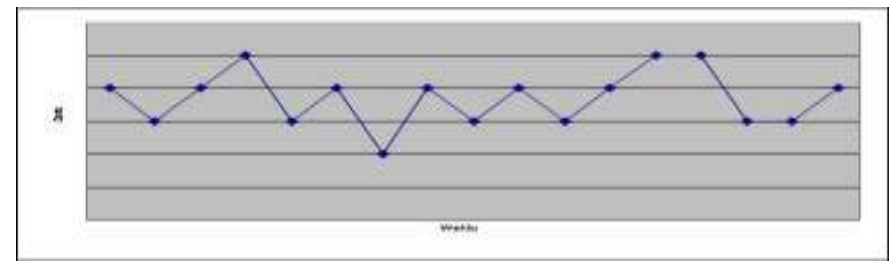

Gambar 1. Contoh Pola Data Horisontal

b. Polamusiman(S)terjadibilamanasuatuderetdipengaruhiolehfaktormusiman (misalnyakuartaltahuntertentu, bulanan, atauhari-haripada minggu tertentu).

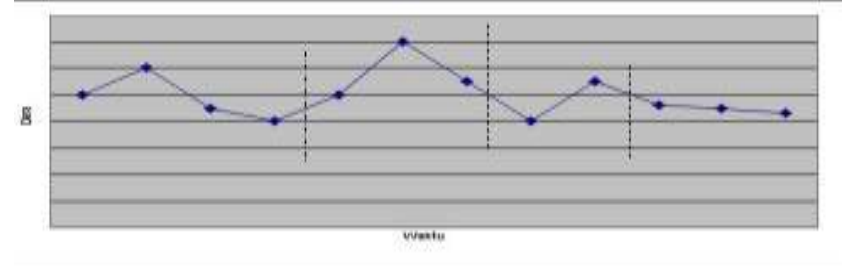

Gambar 2. Contohpola data musiman

c. Polasiklis(C)terjadibilamanadatanyadipengaruhiolehfluktuasiekonomijangkapanjang seperti yang berhubungandengansiklusbisnis. 


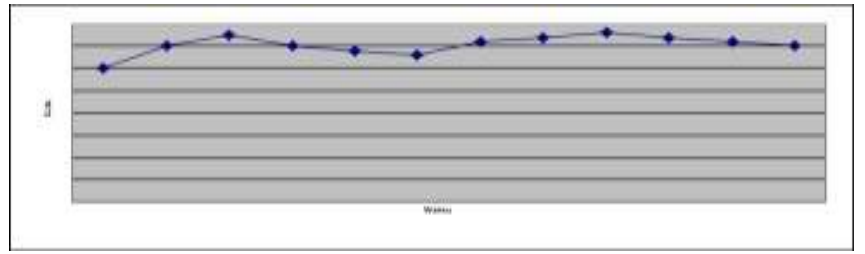

Gambar 3. Contohpola data siklis

d. Polatrend

(T)terjadibilamanaterdapatkenaikanataupenurunansekulerjangkapanjangdalam data.

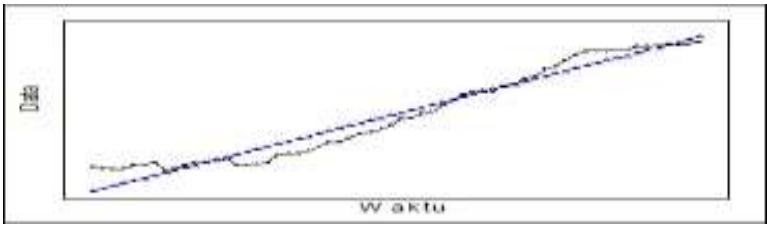

Gambar 4. Contohpola data trend

Ukuran Kesalahan

Deviasi antara nilai aktual dengan nilai taksiran (hasil peramalan) dinamakan kesalahan (error).

Beberapa besaran error yang dikenal adalah :

1. Mean Error $: \mathrm{ME}=\frac{\sum e_{i}}{n}$

2. Mean Absolute Error:MAE $=\frac{\sum\left|e_{i}\right|}{n}$

3. Sum of Sequare Error: $\mathrm{SSE}=\sum e_{i}^{2}$

4. Mean Sequared Error: $\mathrm{MSE}=\frac{\sum\left(e_{i}\right)^{2}}{n}$

5. Standard Deviation of Error: $\mathrm{SDE}=\sqrt{\frac{\sum e_{i}{ }^{2}}{(n-1)}}$

6. Percentage Error: $\mathrm{PE}=\frac{e_{i}}{X_{i}} \times 100 \%$

7. Mean Percentage Error $: \mathrm{MPE}=\frac{\sum P E_{i}}{n}$

8. Mean Absolute Percentage Error: MAPE $=\frac{\sum\left|P E_{i}\right|}{n}$

Catatan $: \mathrm{n}=$ jumlah data.

\section{Metodologi Penelitian}

Penelitian diawali dengan melakukan observasi CV. HN untuk mengetahui kuantitas produksi dan performa penjualan pada produk Lingzhi Plus. Dari observasi didapatkan data penjualan atau data permintaan produk dan data persediaan produk Lingzhi Plus jadi dari bulan Oktober 2014 sampai dengan September 2015.

Untuk mengetahui permintaan pasar akan produk Lingzhi Plus secara tepat dilakukan perhitungan peramalan permintaan dengan beberapa metode. Pada penelitian ini metode peramalan yang digunakan adalah simpleaverage, movingaverage 2, movingaverage 3 , weightedmovingaverage 4, singleexponentialsmoothing, doubleexponentialsmoothingdan regresi linier. Hasil perhitungan tersebut kemudian dievaluasi berdasarkan nilai meanabsolutedeviation(MAD) dan trackingsignal.

Trackingsignaldigunakan sebagai evaluasi kevalidan suatu metode peramalan. Perhitungan ramalan permintaan dianggap valid jika nilai trackingsignalberada pada rentang -4 sampai 
dengan 4. Nilai positif menunjukkan bahwa nilai aktual permintaan lebih besar daripada peramalan sedangakan nilai trackingsignal yang negatif menunjukkan nilai aktual permintaan kurang dari nilai ramalan. Trackingsignal disebut baik apabila memiliki RSFE (runningsum of theforecasterror)yang rendah, dan mempunyai positiveerror yang sama banyak atau seimbang dengan negativeerror, sehingga pusat dari trackingsignal mendekati nol. Maka untuk mendapatkan nilai trackingsignalterlebih dahulu dihitung nilai RSFE.

Sementara itu, MAD digunakan untuk mengevaluasi metode peramalan menggunakan jumlah dari kesalahan-kesalahan yang absolut. MAD mengukur ketepatan ramalan dengan merata-rata kesalahan dugaan (nilai absolut masing-masing kesalahan). Nilai MAD menunjukkan tingkat galat (error) perhitungan ramalan permintaan pada setiap metode. Pemilihan metode terbaik dilakukan dengan melihat nilai MAD.

Jika perhitungan peramalan tersebut valid berdasarkan nilai trackingsignal, maka langkah berikutnya adalah dengan memilih peramalan dengan nilai MAD terkecil sebagai metode terpilih atau terbaik. Berdasarkan perhitungan permintaan terbaik dapat diketahui jumlah produksi yang ideal. Dengan jumlah produksi tersebut kemudian dibandingkan dengan jumlah produksi sebelum peramalan baru untuk mengetahui total biaya yang ditanggung oleh perusahaan karena memproduksi Lingzhi Plus.

\section{Pengumpulan Data}

Data yang dibutuhkan dalam penelitianini adalah data umum perusahaan seperti identitas perusahaan dan data khusus perusahaan seperti data deskripsi produk, data produksi Oktober 2014 - September2015 dan data penjualan Oktober 2014 - September 2015.

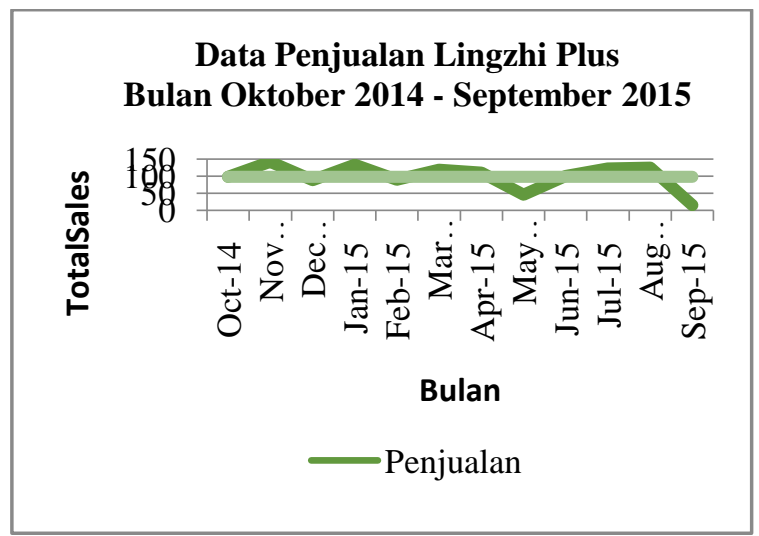

Gambar 5. Grafik Penjualan Lingzhi Plus

\section{Pengolahan Data}

a. Pengolahan Data Peramalan (Forecasting)

Metode peramalan yang digunakan meliputi metode rataan (simpleaverage, movingaverage dan weightedmovingaverage), metode exponentialsmoothing (singleexponentialsmoothing, doubleexponentialsmoothing), regresi linier, dan musiman. Hasil pemgolahan data menggunakan metode tersebut disajikan dalam tabel pada lampiran.

b. Rekapitulasi Nilai MeanAbsoluteDeviation (MAD)

Indikator yang digunakan dalam pengukuran akurasi peramalan adalah nilai MAD. Sementara trackingsignal digunakan untuk memvalidasi model peramalan. 
Tabel 1. Hasil Peramalan Metode Regresi Linier

\begin{tabular}{|c|c|c|c|}
\hline MetodePeramalan & Nilai $M A D$ & Tracking Signal & Keterangan \\
\hline SA & 30.55 & -3.41 & VALID \\
\hline MA2 & 34.75 & -3.27 & VALID \\
\hline MA3 & 35.30 & -2.16 & VALID \\
\hline MA4 & 30.66 & -1.85 & VALID \\
\hline MetodePeramalan & Nilai MAD & Tracking Signal & Keterangan \\
\hline WMA3 & 35.98 & -2.15 & VALID \\
\hline WMA4 & 33.20 & -1.77 & VALID \\
\hline SES & 41.84 & -1.91 & VALID \\
\hline DES & 40.37 & -1.91 & VALID \\
\hline Regresi Linier & 1510.87 & 0.00 & VALID \\
\hline MetodeTerpilih & 30.66 & -1.85 & \\
\hline \multicolumn{4}{|c|}{ MA4 } \\
\hline
\end{tabular}

c. Pengolahan Data Sebelum Peramalan

Perhitungan data sebelum peramalan didasarkan data produksi dan penjualan bulan Februari 2015 - September 2015.

1. Perhitungan Sisa Produksi dan Backorder sebelum Peramalan

Tabel 2. Perhitungan Sisa Produksi dan Backorder sebelum Peramalan

\begin{tabular}{|c|c|c|c|c|}
\hline Bulan & Produksi & Terjual & Sisa & Lost Sales \\
\hline Feb-15 & 124 & 90 & 45 & 0 \\
\hline Mar-15 & 83 & 119 & 9 & 0 \\
\hline Apr-15 & 120 & 110 & 19 & 0 \\
\hline Mei-15 & 117 & 45 & 91 & 0 \\
\hline Jun-15 & 44 & 100 & 35 & 0 \\
\hline Jul-15 & 98 & 122 & 11 & 0 \\
\hline August-15 & 117 & 125 & 3 & 0 \\
\hline Sep-15 & 120 & 15 & 108 & 0 \\
\hline
\end{tabular}

2. Perhitungan Biaya Simpan sebelum Peramalan

Kapasitas penyimpanan $=48$ unit

Daya $=160 \mathrm{watt}$

Penggunaan $/$ bulan $=672 \mathrm{jam}=107.520 \mathrm{Wh} \quad=107,52 \mathrm{kWh}$

Tabel 3. Perhitungan Biaya Simpan sebelum Peramalan

\begin{tabular}{|c|c|c|c|c|c|c|c|c|c|c|c|}
\hline Bulan & Sisa & Lost Sales & Harga/unit & KWH & Tarif/KWH & \multicolumn{2}{|c|}{ Biaya Listrik } & \multicolumn{2}{|c|}{ Capital Cost } & \multicolumn{2}{|c|}{ Total Biaya simpan } \\
\hline Feb-15 & 45 & 0 & $\mathrm{Rp} 33,000$ & 107.52 & $\mathrm{Rp} \quad 1,427$ & $\mathrm{Rp}$ & 153,386 & $\mathrm{Rp}$ & 9,281 & $\mathrm{Rp}$ & 162,667 \\
\hline Mar-15 & 9 & 0 & Rp 33,000 & 107.52 & $\mathrm{Rp} \quad 1,427$ & $\mathrm{Rp}$ & 153,386 & $\mathrm{Rp}$ & 1,856 & $\mathrm{Rp}$ & 155,242 \\
\hline Apr-15 & 19 & 0 & $\operatorname{Rp} 33,000$ & 107.52 & $\mathrm{Rp} \quad 1,427$ & $\mathrm{Rp}$ & 153,386 & $\mathrm{Rp}$ & 3,919 & $\mathrm{Rp}$ & 157,305 \\
\hline Mei-15 & 91 & 0 & $\operatorname{Rp} 33,000$ & 215.04 & $\mathrm{Rp} \quad 1,427$ & $\mathrm{Rp}$ & 306,772 & $\mathrm{Rp}$ & 18,769 & $\mathrm{Rp}$ & 325,541 \\
\hline Jun-15 & 35 & 0 & $\operatorname{Rp} 33,000$ & 107.52 & $\operatorname{Rp} 1,427$ & $\mathrm{Rp}$ & 153,386 & $\mathrm{Rp}$ & 7,219 & $\mathrm{Rp}$ & 160,605 \\
\hline Jul-15 & 11 & 0 & $\operatorname{Rp~} 33,000$ & 215.04 & $\mathrm{Rp} \quad 1,427$ & $\mathrm{Rp}$ & 153,386 & $\mathrm{Rp}$ & 2,269 & $\mathrm{Rp}$ & 155,655 \\
\hline August-15 & 3 & 0 & $\operatorname{Rp~} 33,000$ & 107.52 & $\mathrm{Rp} \quad 1,427$ & $\mathrm{Rp}$ & 153,386 & $\mathrm{Rp}$ & 619 & $\mathrm{Rp}$ & 154,005 \\
\hline Sep-15 & 108 & 0 & Rp 33,000 & & & & & & & & \\
\hline \multicolumn{10}{|c|}{ Biaya waste } & $\mathrm{Rp}$ & 712,800 \\
\hline \multicolumn{10}{|c|}{ Total } & $\mathrm{Rp}$ & $1,983,919$ \\
\hline
\end{tabular}

3. Perhitungan Biaya WasteDisposal sebelum Peramalan

Perhitungan biaya wastedisposaldialkukan pada akhir akumulasi yaitu pemberian potongan harga sebesar $20 \%$.

Biaya WasteDisposal = Unit akhir akumulasi $\mathrm{x}$ Diskon $\mathrm{x}$ Harga per unit 


$$
\begin{aligned}
& =108 \times 20 \% \times \mathrm{Rp} 33.000,00 \\
& =\mathrm{Rp} 712.000,00
\end{aligned}
$$

4. Perhitungan Capital Cost

Perhitungan capitalcost didasarkan pada bunga bank BI pada tahun 2015 yaitu sebesar $7.5 \%$ per tahun, yang berarti sebesar $0.625 \%$ per bulan.

Capital cost per unit = bunga bank BI per bulan $\mathrm{x}$ harga per unit

$=0.625 \% \times \mathrm{Rp} 33,000$

$=\operatorname{Rp} 206.25$

d. Pengolahan Data Setelah Peramalan

Perhitungan data setelah peramalan dilakukan berdasarkan hasil peramalan dengan metode MA4 dan data penjualan bulan Februari 2015 - September 2015.

1. Perhitungan Sisa Produksi dan Backorder setelah Peramalan

Tabel 4. Perhitungan Sisa Produksi dan Backorder setelah Peramalan

\begin{tabular}{|c|c|c|c|c|}
\hline Ramalan & Produksi & Terjual & Sisa & Lost Sales \\
\hline 115 & 145 & 90 & 55 & \\
\hline 113 & 88 & 119 & 24 & \\
\hline 107 & 113 & 116 & 21 & \\
\hline 113 & 122 & 48 & 95 & \\
\hline 91 & 26 & 100 & 21 & \\
\hline 93 & 102 & 122 & 1 & \\
\hline 94 & 123 & 125 & & 2 \\
\hline 98 & 130 & 17 & 113 & \\
\hline
\end{tabular}

2. Perhitungan Biaya Simpan setelah Peramalan

\begin{tabular}{|c|c|c|c|c|c|c|c|c|}
\hline Ramalan & Produksi & Terjual & Sisa & Lost Sales & Biaya lost sales & Biaya listrik untuk penyimpanan & capital cost & Total Biaya simpan \\
\hline 115 & 145 & 90 & 55 & & & 306,772 & 11,344 & 318,116 \\
\hline 113 & 88 & 119 & 24 & & & 153,386 & 4,950 & 158,336 \\
\hline 107 & 113 & 116 & 21 & & & 153,386 & 4,331 & 157,717 \\
\hline 113 & 122 & 48 & 95 & & & 306,772 & 19,594 & 326,366 \\
\hline 91 & 26 & 100 & 21 & & & 153,386 & 4,331 & 157,717 \\
\hline 93 & 102 & 122 & 1 & & & 153,386 & 206 & 153,592 \\
\hline 94 & 123 & 125 & & 2 & 66,000 & & & \\
\hline 98 & 130 & 17 & 113 & & & & & \\
\hline \multicolumn{8}{|c|}{ Biaya Waste } & 745,800 \\
\hline \multicolumn{8}{|c|}{ Lost Sales } & 66,000 \\
\hline \multicolumn{8}{|c|}{ Total } & $1,772,334$ \\
\hline
\end{tabular}

Tabel 5. Perhitungan Biaya Simpan setelah Peramalan

3. Perhitungan Biaya Capital Cost setelah Peramalan

Perhitungan biaya capitalcost menggunakan suku bunga Bank Indonesia yaiu $7,5 \% /$ tahun

Tabel 6. Perhitungan Biaya Backorder setelah Peramalan

\begin{tabular}{|c|c|c|c|c|c|c|c|c|}
\hline Ramalan & Produksi & Terjual & Sisa & Lost Sales & Suku Bunga & Harga/unit & Capital cost/Unit & capital cost \\
\hline 115 & 145 & 90 & 55 & & $0.625 \%$ & 33,000 & 206.25 & 11,344 \\
\hline 113 & 88 & 119 & 24 & & $0.625 \%$ & 33,000 & 206.25 & 4,950 \\
\hline 107 & 113 & 116 & 21 & & $0.625 \%$ & 33,000 & 206.25 & 4,331 \\
\hline 113 & 122 & 48 & 95 & & $0.625 \%$ & 33,000 & 206.25 & 19,594 \\
\hline 91 & 26 & 100 & 21 & & $0.625 \%$ & 33,000 & 206.25 & 4,331 \\
\hline 93 & 102 & 122 & 1 & & $0.625 \%$ & 33,000 & 206.25 & 206 \\
\hline 94 & 123 & 125 & & 2 & $0.625 \%$ & 33,000 & 206.25 & \\
\hline 98 & 130 & 17 & 113 & & $0.625 \%$ & 33,000 & 206.25 & \\
\hline
\end{tabular}

4. Perhitungan Biaya WasteDisposal setelah Peramalan 
Perhitungan biaya wastedialkukan pada akhir akumulasi yaitu pemberian potongan harga sebesar $20 \%$.

Biaya WasteDisposal

$=$ Unit akhir akumulasi $\mathrm{x}$ Diskon $\mathrm{x}$ Harga per unit

$=113 \times 20 \% \times \mathrm{Rp} 33.000,00$

$=\mathrm{Rp} 745.800,00$

e. Perbandingan Biaya Sebelum dan Sesudah Peramalan

Tabel 7. Perbandingan Biaya Sebelum dan Sesudah Peramalan

\begin{tabular}{|c|lr|lr|}
\hline Biaya & \multicolumn{2}{|l|}{ Sebelum Peramalan } & \multicolumn{2}{l|}{ Setelah Peramalan } \\
\hline Biaya Simpan & $\mathrm{Rp}$ & $1,314,950$ & $\mathrm{Rp}$ & 960,534 \\
\hline Biaya Lost Sales & $\mathrm{Rp}$ & - & $\mathrm{Rp}$ & 66,000 \\
\hline Biaya Waste & $\mathrm{Rp}$ & 712,800 & $\mathrm{Rp}$ & 745,800 \\
\hline Total & $\mathrm{Rp}$ & $1,983,919$ & $\mathrm{Rp}$ & $1,772,334$ \\
\hline Selisih & $\mathrm{Rp}$ & \multicolumn{3}{|c|}{} \\
\hline
\end{tabular}

\section{Analisis}

Berdasarkan grafik data penjualan periode Oktober 2014 - September 2015 dapat diketahui memiliki pola penjualan horisondimana penjualan sangat fluktuatif. Pemilihan metode yang lebih cocok untuk data yang fluktuatif adalah movingaverage,weightedmovingaverage, singleexponentialsmoothing, dan doubleexponentialsmoothing. Pada metode peramalan SES dan DES digunakan koefisien pemulusan sebesar 0,9 karena data sangat fluktuatif. Rentang penerimaaan metode peramalan yang digunakan mengacu pada Heizer dan Render (2009), yitu antara -4 dan 4.

Peramalan menghasilkan trackingsignaldiantara -4 dan 4, sehingga metode peramalan tersebut valid atau baik digunakan untuk kasus penjualan Lingzhi Plus. Kemudian peramalan dengan MA2 didapatkan nilai MAD sebesar 34,75, MA3 sebesar 35,30, MA4 sebesar 30,66, WMA3 sebesar 35,98, WMA4 sebesar 33,20, SES sebesar 41,84, DES sebesar 40,37, dan regresi linier sebesar 1510,87 . Dari perhitungan dengan semua metode tersebut, peramalan dengan metode SA memiliki nilai MAD yang lebih kecil, menandakan bahwa memiliki tingkat error yang lebih kecil dibanding dengan metode lain. Namun, untuk kasus penjualan Lingzhi Plus yang berfluktuatif metode tersebut kurang cocok. Maka dari itu, MA4 dengan nilai MAD terkecil kedua lebih cocok untuk meramalkan penjualan Lingzhi Plus.

Setelah dilakukan peramalan untuk menentukan jumlah unit yang harus diproduksi, dilakukan analisis perbandingan biaya sebelum dan setelah dilakukan peramalan. Peramalan MA4 menghasilkan data unit yang harus diproduksi dari bulan Februari 2015 - Oktober 2015, dan data aktual yang diperoleh menunjukkan data produksi dan permintaan dari bulan Oktober 2014- September 2015, sehingga data yang dibandingkan adalah biaya produksi dengan menggunakan ramalan dan aktual periode Februari 2015 - September 2015. Jika perusahaan melakukan produksi berdasarkan hasil peramalan pada bulan Februari 2015 - September 2015, terdapat LostSales di bulan Agustus. Sedangkan penyimpanan stockterjadi pada bulan Februari, Maret, April, Mei, Juni, Juli, dan September. Akumulasi produk akhir tahun adalah 113 unit. Jumlah unit yang harus diproduksi merupakan penjumlahan dari ramalan dan safetystockperusahaan sebesar 30 unit.

Data aktual produksi dan permintaan yang diperoleh menunjukkan bahwa pada periode Februari 2015 - September 2015 tidak terjadi lostsales. Setiap bulan terdapat sisa unit yang cukup banyak. Sisa produk tersebut harus disimpan dalam showcaseberkapasitas 48 botol, untuk menjaga kualitasnya. Untuk itu, perusahaan harus menanggung biaya simpan, yaitu biaya listrik showcase per periode penyimpanan produk. Showcasemembutuhkan daya 160 watt per jam, dan produk disimpan selama 28 hari dalam sebulan. Biaya yang dikeluarkan didasarkan pada tarif 
listrik PLN bulan Maret 2015 yaitu sebesar Rp 1426,58/kwh. Sehingga total biaya simpan yang dikeluarkan dalam periode Februari 2015 - September 2015 sebesar Rp 1.227.087,053. Perusahaan tutup buku dan melakukan cuci gudang untuk produk-produk yang mendekati expireddate setiap September, dengan memberikan diskon sebesar $20 \%$ per unit. Sehingga dalam kasus ini, selain mengeluarkan biaya simpan, perusahaan juga menanggung biaya wastedisposal, yaitu biaya untuk menghabiskan stockyang didapat dari diskon dikalikan jumlah produk yang harus dihabiskan di akhir periode, dengan total sebesar Rp712.800,00. Jadi, total biaya inventoryyang harus ditanggung perusahaan jika memproduksi unit tanpa melakukan peramalan pada periode Februari 2015 - September 2015 adalah penjumlahan biaya simpan dan biaya wastedisposalyaitu sebesar Rp 1.983.919,00.

Setelah dilakukan peramalan, dan menganalisa jika perusahaan melakukan produksi sesuai dengan ramalan, jumlah unit yang harus disimpan setiap bulannya dan jumlah unit yang harus dihabiskan pada akhir September 2015 lebih sedikit dibanding data aktual. Biaya simpan perusahaan setelah melakukan peramalan mengalami penurunan, karena unit yang disimpan tiap bulan juga mengalami penurunan. Biaya simpan yang dikeluarkan sebesar Rp 960,534 dan biaya wastedisposalpada akhir tahun sebesar Rp 745.800, sehingga total biaya yang ditanggung perusahaan sebesar Rp 1,772,334. Jadi, dengan melakukan peramalan, perusahaan bisa menghemat biaya sebesar Rp 211,585 untuk periode Februari 2015 - September 2015.

\section{Simpulan}

Penyebab masalah overstockproduk Lingzhi Plus pada CV. HNadalah pemilihan metode peramalan permintaan yang kurang tepat. Metode peramalan yang digunakan perusahaan saat ini hanya berdasarkan rata-rata permintaan tahunan. Pemilihan metode tersebut belum dievaluasi dan dibandingkan dengan metode peramalan lain yang mungkin lebih tepat digunakan. Kemudian dari penelitian diusulkan untuk memperbaiki metode peramalan untuk mengendalikan persediaan berlebih. Metode peramalan yang cocok digunakan untuk pola data pada perusahaan CV. HN adalah movingaverage4. Dengan melakukan peramalan tersebut, perusahaan menanggung biaya wastedisposal dan biaya simpan lebih sedikit, sehingga dihasilkan penghematan sebesar Rp 211,585 untuk periode Februari 2015 - September 2015.

Saran untuk penelitian terkait dimasa mendatang yaitu peramalan dari data historis yang lebih panjang, yaitu lebih dari satu tahun, dapat dikembangkan untuk penelitian selanjutnya. Selain itu, dapat pula dipertimbangkan untuk mengendalikan pembelian bahan baku, untuk meminimasipersediaan pada perusahaan ini.

\section{Lampiran}

a. Peramalan SimpleAverage

Hasil perhitungan jumlah permintaan dengan menggunakan peramalan metode simpleaverage dapat dilihat pada tabel berikut

Tabel 8. Hasil Peramalan SimpleAverageProduk Lingzhi Plus CV. HN

\begin{tabular}{rrrrrrrr}
\hline Bulan & $\begin{array}{c}\text { Actual } \\
\text { Demand }\end{array}$ & $\begin{array}{c}\text { Demand } \\
\text { Forecast }\end{array}$ & \multicolumn{1}{l}{ Error } & $\begin{array}{c}\text { Absolute } \\
\text { Error }\end{array}$ & Mad & Rsfe & $\begin{array}{c}\text { Tracking } \\
\text { Signal }\end{array}$ \\
\hline Oct-14 & 98 & & & & & & \\
\hline Nov-14 & 142 & 98.00 & 44.00 & 44.00 & 44.00 & 44.00 & 1.00 \\
\hline Dec-14 & 88 & 120.00 & -32.00 & 32.00 & 38.00 & 12.00 & 0.32 \\
\hline Jan-15 & 133 & 109.33 & 23.67 & 23.67 & 33.22 & 35.67 & 1.07 \\
\hline Feb-15 & 90 & 115.25 & -25.25 & 25.25 & 31.23 & 10.42 & 0.33 \\
\hline Mar-15 & 119 & 110.20 & 8.80 & 8.80 & 26.74 & 19.22 & 0.72 \\
\hline Apr-15 & 110 & 111.67 & -1.67 & 1.67 & 22.56 & 17.55 & 0.78 \\
\hline May-15 & 45 & 111.43 & -66.43 & 66.43 & 28.83 & -48.88 & -1.70 \\
\hline Jun-15 & 100 & 103.13 & -3.13 & 3.13 & 25.62 & -52.00 & -2.03 \\
\hline
\end{tabular}




\begin{tabular}{crrrrrrr}
\hline Jul-15 & 122 & 102.78 & 19.22 & 19.22 & 24.91 & -32.78 & -1.32 \\
\hline Aug-15 & 125 & 104.70 & 20.30 & 20.30 & 24.45 & -12.48 & -0.51 \\
\hline Sep-15 & 15 & 106.55 & -91.55 & 91.55 & 30.55 & -104.03 & -3.41 \\
\hline Oct-15 & & 98.92 & & & & & \\
\hline
\end{tabular}

b. Peramalan Metode MovingAverage

Hasil perhitungan jumlah permintaan dengan menggunakan peramalan metode movingaverage dengan periode 4 bulan dapat dilihat pada berikut.

Tabel 9. Hasil Peramalan MovingAverage4

\begin{tabular}{|c|c|c|c|c|c|c|c|}
\hline Bulan & $\begin{array}{l}\text { Actual } \\
\text { demand }\end{array}$ & $\begin{array}{l}\text { Demand } \\
\text { forecast }\end{array}$ & Error & $\begin{array}{l}\text { Absolute } \\
\text { error }\end{array}$ & MAD & RSFE & $\begin{array}{l}\text { Tracking } \\
\text { signal }\end{array}$ \\
\hline Oct-14 & 98 & & & & & & \\
\hline Nov-14 & 142 & & & & & & \\
\hline Dec-14 & 88 & & & & & & \\
\hline Jan-15 & 133 & & & & & & \\
\hline Feb-15 & 90 & 115.25 & 17.75 & 17.75 & 17.75 & 10742.96 & 0.28 \\
\hline Mar-15 & 119 & 113.25 & 5.75 & 5.75 & 11.75 & 10742.96 & 0.05 \\
\hline Apr-15 & 110 & 107.50 & 2.50 & 2.50 & 8.67 & 10742.96 & 0.02 \\
\hline May-15 & 45 & 113.00 & -68.00 & 68.00 & 23.50 & 10742.96 & 1.51 \\
\hline Jun-15 & 100 & 91.00 & 9.00 & 9.00 & 20.60 & 10742.96 & 0.09 \\
\hline Jul-15 & 122 & 93.50 & 28.50 & 28.50 & 21.92 & 10742.96 & 0.23 \\
\hline Aug-15 & 125 & 94.25 & 30.75 & 30.75 & 23.18 & 10742.96 & 0.25 \\
\hline Sep-15 & 15 & 98.00 & -83.00 & 83.00 & 30.66 & 10742.96 & 5.53 \\
\hline Oct-15 & & 90.50 & & & & & \\
\hline
\end{tabular}

Hasil perhitungan jumlah permintaan dengan menggunakan peramalan metode movingaverage dengan periode 3 bulan dapat dilihat pada tabel berikut.

Tabel 10. Hasil Peramalan MovingAverage3

\begin{tabular}{rrrrrrrr}
\hline \multicolumn{1}{c}{ Bulan } & $\begin{array}{c}\text { Actual } \\
\text { demand }\end{array}$ & $\begin{array}{c}\text { Demand } \\
\text { forecast }\end{array}$ & Error & $\begin{array}{c}\text { Absolute } \\
\text { error }\end{array}$ & MAD & RSFE & $\begin{array}{c}\text { Tracking } \\
\text { signal }\end{array}$ \\
\hline Oct-14 & 98 & & & & & & \\
\hline Nov-14 & 142 & & & & & & \\
\hline Dec-14 & 88 & & & & & & \\
\hline Jan-15 & 133 & 109.33 & 23.67 & 23.67 & 23.67 & 23.67 & 1.00 \\
\hline Feb-15 & 90 & 121.00 & -31.00 & 31.00 & 27.33 & -7.33 & -0.27 \\
\hline Mar-15 & 119 & 103.67 & 15.33 & 15.33 & 23.33 & 8.00 & 0.34 \\
\hline Bulan & $\begin{array}{r}\text { Actual } \\
\text { demand }\end{array}$ & $\begin{array}{r}\text { Demand } \\
\text { forecast }\end{array}$ & Error & $\begin{array}{r}\text { Absolute } \\
\text { error }\end{array}$ & MAD & RSFE & Tracking \\
signal \\
\hline Apr-15 & 110 & 114.00 & -4.00 & 4.00 & 18.50 & 4.00 & 0.22 \\
\hline May-15 & 45 & 106.33 & -61.33 & 61.33 & 27.07 & -57.33 & -2.12 \\
\hline Jun-15 & 100 & 91.33 & 8.67 & 8.67 & 24.00 & -48.67 & -2.03 \\
\hline Jul-15 & 122 & 85.00 & 37.00 & 37.00 & 25.86 & -11.67 & -0.45 \\
\hline Aug-15 & 125 & 89.00 & 36.00 & 36.00 & 27.13 & 24.33 & 0.90 \\
\hline Sep-15 & 15 & 115.67 & -100.67 & 100.67 & 35.30 & -76.33 & -2.16 \\
\hline Oct-15 & & 87.33 & & & & & \\
\hline
\end{tabular}


Hasil perhitungan jumlah permintaan dengan menggunakan peramalan metode movingaverage dengan periode 2 bulan dapat dilihat pada tabel berikut.

Tabel 11. Hasil Peramalan MovingAverage 2

\begin{tabular}{rrrrrrrr}
\hline \multicolumn{1}{c}{ Bulan } & $\begin{array}{c}\text { Actual } \\
\text { demand }\end{array}$ & $\begin{array}{c}\text { Demand } \\
\text { forecast }\end{array}$ & Error & $\begin{array}{c}\text { Absolute } \\
\text { error }\end{array}$ & MAD & RSFE & $\begin{array}{c}\text { Tracking } \\
\text { signal }\end{array}$ \\
\hline Oct-14 & 98 & & & & & & \\
\hline Nov-14 & 142 & & & & & & \\
\hline Dec-14 & 88 & 120.00 & -32.00 & 32.00 & 32.00 & -32.00 & -1.00 \\
\hline Jan-15 & 133 & 115.00 & 18.00 & 18.00 & 25.00 & -14.00 & -0.56 \\
\hline Feb-15 & 90 & 110.50 & -20.50 & 20.50 & 23.50 & -34.50 & -1.47 \\
\hline Mar-15 & 119 & 111.50 & 7.50 & 7.50 & 19.50 & -27.00 & -1.38 \\
\hline Apr-15 & 110 & 104.50 & 5.50 & 5.50 & 16.70 & -21.50 & -1.29 \\
\hline May-15 & 45 & 114.50 & -69.50 & 69.50 & 25.50 & -91.00 & -3.57 \\
\hline Jun-15 & 100 & 77.50 & 22.50 & 22.50 & 25.07 & -68.50 & -2.73 \\
\hline Jul-15 & 122 & 72.50 & 49.50 & 49.50 & 28.13 & -19.00 & -0.68 \\
\hline Aug-15 & 125 & 111.00 & 14.00 & 14.00 & 26.56 & -5.00 & -0.19 \\
\hline Sep-15 & 15 & 123.50 & -108.50 & 108.50 & 34.75 & -113.50 & -3.27 \\
\hline Oct-15 & & 70.00 & & & & & \\
\hline
\end{tabular}

c. Peramalan Metode WeightedMovingAverage

Hasil perhitungan jumlah permintaan dengan menggunakan peramalan metode weightedmovingaverage dengan periode 4 bulan dapat dilihat pada tabel berikut.

Tabel 12. Hasil Peramalan WeightedMovingAverage4

\begin{tabular}{rrrrrrrr}
\hline \multicolumn{1}{c}{ Bulan } & $\begin{array}{c}\text { Actual } \\
\text { demand }\end{array}$ & $\begin{array}{c}\text { Demand } \\
\text { forecast }\end{array}$ & Error & $\begin{array}{c}\text { Absolute } \\
\text { error }\end{array}$ & MAD & RSFE & $\begin{array}{c}\text { Tracking } \\
\text { signal }\end{array}$ \\
\hline Oct-14 & 98 & & & & & & \\
\hline Nov-14 & 142 & & & & & & \\
\hline Dec-14 & 88 & & & & & & \\
\hline Jan-15 & 133 & & & & & & \\
\hline Feb-15 & 90 & 117.80 & 15.20 & 15.20 & 15.20 & 10832.87 & 0.31 \\
\hline Mar-15 & 119 & 107.70 & 11.30 & 11.30 & 13.25 & 10832.87 & 0.09 \\
\hline Apr-15 & 110 & 110.00 & 0.00 & 0.00 & 8.83 & 10832.87 & 0.00 \\
\hline May-15 & 45 & 111.00 & -66.00 & 66.00 & 23.13 & 10832.87 & 1.47 \\
\hline Jun-15 & 100 & 83.80 & 16.20 & 16.20 & 21.74 & 10832.87 & 0.16 \\
\hline Jul-15 & 122 & 87.40 & 34.60 & 34.60 & 23.88 & 10832.87 & 0.28 \\
\hline Aug-15 & 125 & 98.80 & 26.20 & 26.20 & 24.21 & 10832.87 & 0.21 \\
\hline Sep-15 & 15 & 111.10 & -96.10 & 96.10 & 33.20 & 10832.87 & 6.41 \\
\hline Oct-15 & & 77.90 & & & & & \\
\hline & & & & & & &
\end{tabular}

Hasil perhitungan jumlah permintaan dengan menggunakan peramalan metode weightedmovingaverage dengan periode 3 bulan dapat dilihat pada tabel berikut.

Tabel 13. Hasil Peramalan WeightedMovingAverage 3

\begin{tabular}{rrrrrrrr}
\hline \multicolumn{1}{c}{ Bulan } & $\begin{array}{c}\text { Actual } \\
\text { demand }\end{array}$ & $\begin{array}{c}\text { Demand } \\
\text { forecast }\end{array}$ & Error & $\begin{array}{c}\text { Absolute } \\
\text { error }\end{array}$ & MAD & RSFE & $\begin{array}{c}\text { Tracking } \\
\text { signal }\end{array}$ \\
\hline Oct-14 & 98 & & & & & & \\
\hline Nov-14 & 142 & & & & & & \\
\hline Dec-14 & 88 & & & & & & \\
\hline Jan-15 & 133 & 107.67 & 25.33 & 25.33 & 25.33 & 25.33 & 1.00 \\
\hline Feb-15 & 90 & 119.50 & -29.50 & 29.50 & 27.42 & -4.17 & -0.15 \\
\hline Mar-15 & 119 & 104.00 & 15.00 & 15.00 & 23.28 & 10.83 & 0.47 \\
\hline Apr-15 & 110 & 111.67 & -1.67 & 1.67 & 17.88 & 9.17 & 0.51 \\
\hline
\end{tabular}




\begin{tabular}{rrrrrrrr}
\hline May-15 & 45 & 109.67 & -64.67 & 64.67 & 27.23 & -55.50 & -2.04 \\
\hline Jun-15 & 100 & 79.00 & 21.00 & 21.00 & 26.19 & -34.50 & -1.32 \\
\hline Jul-15 & 122 & 83.33 & 38.67 & 38.67 & 27.98 & 4.17 & 0.15 \\
\hline Aug-15 & 125 & 101.83 & 23.17 & 23.17 & 27.38 & 27.33 & 1.00 \\
\hline Sep-15 & 15 & 119.83 & -104.83 & 104.83 & 35.98 & -77.50 & -2.15 \\
\hline Oct-15 & & 69.50 & & & & & \\
\hline
\end{tabular}

d. Peramalan Metode SingleExponentialSmoothing

Hasil perhitungan jumlah permintaan dengan menggunakan peramalan metode singleexponentialsmoothing dengan koefisien pemulusan 0,9 dapat dilihat pada tabel berikut.

Tabel 14. Hasil Peramalan SingleExponentialSmoothing

\begin{tabular}{rrrrrrrr}
\hline \multicolumn{1}{c}{ Bulan } & $\begin{array}{c}\text { Actual } \\
\text { demand }\end{array}$ & $\begin{array}{c}\text { Demand } \\
\text { forecast }\end{array}$ & Error & $\begin{array}{c}\text { Absolute } \\
\text { error }\end{array}$ & MAD & RSFE & $\begin{array}{c}\text { Tracking } \\
\text { signal }\end{array}$ \\
\hline Oct-14 & 98 & & & & & & \\
\hline Nov-14 & 142 & 98.00 & 44.00 & 44.00 & 44.00 & 11807.52 & 44.00 \\
\hline Dec-14 & 88 & 137.60 & -49.60 & 49.60 & 46.80 & 11807.52 & -5.60 \\
\hline Jan-15 & 133 & 92.96 & 40.04 & 40.04 & 44.55 & 11807.52 & 34.44 \\
\hline Feb-15 & 90 & 129.00 & -39.00 & 39.00 & 43.16 & 11807.52 & -4.56 \\
\hline Mar-15 & 119 & 93.90 & 25.10 & 25.10 & 39.55 & 11807.52 & 20.54 \\
\hline Apr-15 & 110 & 116.49 & -6.49 & 6.49 & 34.04 & 11807.52 & 14.05 \\
\hline May-15 & 45 & 110.65 & -65.65 & 65.65 & 38.55 & 11807.52 & -51.59 \\
\hline Jun-15 & 100 & 51.56 & 48.44 & 48.44 & 39.79 & 11807.52 & -3.16 \\
\hline Jul-15 & 122 & 95.16 & 26.84 & 26.84 & 38.35 & 11807.52 & 23.68 \\
\hline Aug-15 & 125 & 119.32 & 5.68 & 5.68 & 35.08 & 11807.52 & 29.37 \\
\hline Sep-15 & 15 & 124.43 & -109.43 & 109.43 & 41.84 & 11807.52 & -80.06 \\
\hline Oct-15 & & 25.94 & & & & & \\
\hline
\end{tabular}

e. Peramalan Metode DoubleExponentialSmoothing

Hasil perhitungan jumlah permintaan dengan menggunakan peramalan metode doubleexponentialsmoothing dengan koefisien pemulusan 0,9 dapat dilihat pada tabel 9 .

Tabel 15. Hasil Peramalan DoubleExponentialSmoothing

\begin{tabular}{|r|r|r|r|r|r|r|r|r|}
\hline Bulan & $\begin{array}{c}\text { Actual } \\
\text { demand }\end{array}$ & $\begin{array}{c}\text { Forecast } \\
\text { SES }\end{array}$ & $\begin{array}{c}\text { Forecast } \\
\text { DES }\end{array}$ & Error & $\begin{array}{c}\text { Absolute } \\
\text { error }\end{array}$ & MAD & RSFE & $\begin{array}{c}\text { Tracking } \\
\text { signal }\end{array}$ \\
\hline Oct-14 & 98 & & & & & & & \\
\hline Nov-14 & 142 & 98.00 & 98.00 & 44.00 & 44.00 & 44.00 & 44.00 & 1.00 \\
\hline Dec-14 & 88 & 137.60 & 133.64 & -45.64 & 45.64 & 44.82 & -1.64 & -0.04 \\
\hline Jan-15 & 133 & 92.96 & 97.03 & 35.97 & 35.97 & 41.87 & 34.33 & 0.82 \\
\hline Feb-15 & 90 & 129.00 & 125.80 & -35.80 & 35.80 & 40.35 & -1.47 & -0.04 \\
\hline Mar-15 & 119 & 93.90 & 97.09 & 21.91 & 21.91 & 36.66 & 20.44 & 0.56 \\
\hline Apr-15 & 110 & 116.49 & 114.55 & -4.55 & 4.55 & 31.31 & 15.89 & 0.51 \\
\hline
\end{tabular}

\begin{tabular}{|c|c|c|c|c|c|c|c|c|}
\hline Bulan & $\begin{array}{c}\text { Actual } \\
\text { demand }\end{array}$ & $\begin{array}{c}\text { Forecast } \\
\text { SES }\end{array}$ & $\begin{array}{c}\text { Forecast } \\
\text { DES }\end{array}$ & Error & $\begin{array}{c}\text { Absolute } \\
\text { error }\end{array}$ & MAD & RSFE & $\begin{array}{c}\text { Tracking } \\
\text { signal }\end{array}$ \\
\hline
\end{tabular}




\begin{tabular}{|r|r|r|r|r|r|r|r|r|}
\hline May-15 & 45 & 110.65 & 111.04 & -66.04 & 66.04 & 36.27 & -50.15 & -1.38 \\
\hline Jun-15 & 100 & 51.56 & 57.51 & 42.49 & 42.49 & 37.05 & -7.66 & -0.21 \\
\hline Jul-15 & 122 & 95.16 & 91.39 & 30.61 & 30.61 & 36.33 & 22.95 & 0.63 \\
\hline Aug-15 & 125 & 119.32 & 116.52 & 8.48 & 8.48 & 33.55 & 31.43 & 0.94 \\
\hline Sep-15 & 15 & 124.43 & 123.64 & -108.64 & 108.64 & 40.37 & -77.21 & -1.91 \\
\hline
\end{tabular}

f. Peramalan Metode Regresi Linier

Hasil perhitungan jumlah permintaan dengan menggunakan peramalan metode regresi linier dapat dilihat pada tabel 10.

Tabel 16. Hasil Peramalan Metode Regresi Linier

\begin{tabular}{|c|c|c|c|c|c|c|c|c|c|}
\hline Bulan & $\begin{array}{c}\text { Actual } \\
\text { deman } \\
\mathbf{d}(\mathbf{D t})\end{array}$ & $\mathbf{T . D t}$ & $\mathbf{t}^{2}$ & $\begin{array}{c}\text { Deman } \\
\mathbf{d} \\
\text { forecast } \\
\text { (D') }\end{array}$ & Error & $\begin{array}{c}\text { Absolut } \\
\text { e error }\end{array}$ & MAD & RSFE & $\begin{array}{c}\text { Tracki } \\
\text { ng } \\
\text { signal }\end{array}$ \\
\hline Oct-14 & 98 & 98 & 1 & 2892.23 & -2794.23 & 2794.23 & 2794.23 & -2794.23 & -1.00 \\
\hline Nov-14 & 142 & 284 & 4 & 2384.35 & -2242.35 & 2242.35 & 2518.29 & -5036.58 & -2.00 \\
\hline Dec-14 & 88 & 264 & 9 & 1876.48 & -1788.48 & 1788.48 & 2275.02 & -6825.06 & -3.00 \\
\hline Jan-15 & 133 & 532 & 16 & 1368.60 & -1235.60 & 1235.60 & 2015.17 & -8060.66 & -4.00 \\
\hline Feb-15 & 90 & 450 & 25 & 860.73 & -770.73 & 770.73 & 1766.28 & -8831.39 & -5.00 \\
\hline Mar-15 & 119 & 714 & 36 & 352.85 & -233.85 & 233.85 & 1510.87 & -9065.24 & -6.00 \\
\hline Apr-15 & 110 & 770 & 49 & -155.02 & 265.02 & 265.02 & 1332.89 & -8800.22 & -6.60 \\
\hline May-15 & 45 & 360 & 64 & -662.90 & 707.90 & 707.90 & 1254.77 & -8092.33 & -6.45 \\
\hline Jun-15 & 100 & 900 & 81 & -1170.77 & 1270.77 & 1270.77 & 1256.55 & -6821.56 & -5.43 \\
\hline Jul-15 & 122 & 1220 & 100 & -1678.64 & 1800.64 & 1800.64 & 1310.96 & -5020.91 & -3.83 \\
\hline Aug-15 & 125 & 1375 & 121 & -2186.52 & 2311.52 & 2311.52 & 1401.92 & -2709.39 & -1.93 \\
\hline Sep-15 & 15 & 180 & 144 & -2694.39 & 2709.39 & 2709.39 & 1510.87 & 0.00 & 0.00 \\
\hline Oct-15 & & & & -2694.39 & & & & & \\
\hline
\end{tabular}

\section{Daftar Pustaka}

Arisandhy, Vivi, Silalahi, Lydiawari. Suhandi, Victor. (2010). Analisis Pengendalian Persediaan Produk Jadi pada PT. URCV Indonesia yang Dikelola oleh Bagian Modern Trade. Bandung : Universitas Kristen Maranatha.

Buffa, Elwood S.,danSarin, R. K. (1996). ManajemenOperasidanProduksi Modern. Edisi 8. Jakarta: BinarupaAksara.

Hanke, J. E., \&ReUsch, A. G. (1998). Business forecasting $\left(6^{\text {th }}\right.$ ed). UpperSaddle River, NJ: PrenticeHaU. Hansen, S. (2013). Penerapan WEMA dalam Peramalan Data IHSG. ULTIMATICS, Vol. V, No. 2. Tangerang : Program Studi Informatika, Universitas Multimedia Nusantara.

Kusharyanto, A. (2011). Analisis Peramalan Penjualan Buku Pelajaran Jenis Lks Pada Cv. Harapan Baru Karanganyar. Surakarta : Universitas Negeri Sebelas Maret.

Makridakis, S., Wheelwright, S. C. \&Hyndman, R. J. (1998). ForecastinggMethodsandApplication $\left(3^{\text {rd }}\right.$ ed). John Willey\& Sons, Inc.

Messersmith, A. M., \& Miller, J. L. (1991). ForecastinginFoodservice. New York: John Willey\& Sons, Inc.

Muckstadt, John A., Sapra, Amar. (2010). Principles of Inventory Management : WhenYouareDowntoFour, Order More. New York : Springer

Rushton, Alan, Croucher, Phil, Baker, Peter. (2006). The handbook of LogisticsandDistribution Management $3{ }^{\text {rd }}$ Edition. London : KoganPage.

Ryu, K. (2002). The Evaluation of ForecastingMethodsatanInstitutionalFoodserviceDiningFacility.Texas Technology University, Texas 